\title{
PENTINGNYA EDUKASI KEUANGAN KELUARGA
}

\author{
Suramaya Suci Kewal ${ }^{1}$ \\ Fakultas Bisnis dan Akuntasi, Universitas Katolik Musi Charitas \\ Email : suramaya@ukmc.ac.id \\ Yohanes Andri Putranto ${ }^{2}$ \\ Fakultas Bisnis dan Akuntasi, Universitas Katolik Musi Charitas \\ Email : andri@ukmc.ac.id \\ Anastasia Sri Mendari ${ }^{3}$ \\ Fakultas Bisnis dan Akuntasi, Universitas Katolik Musi Charitas \\ Email : anastasia@ukmc.ac.id
Heriyanto $^{4}$
Fakultas Bisnis dan Akuntasi, Universitas Katolik Musi Charitas
Email : heriyanto@ukmc.ac.id \\ AgustinusWidyartono ${ }^{* 5}$ \\ Fakultas Bisnis dan Akuntasi, Universitas Katolik Musi Charitas \\ Email : widyartono@ukmc.ac.id
}

\begin{abstract}
A good family needs to be prepared for a long time, because a good family is the main factor for personal, community and church safety/welfare, in building a Catholic family, one of the important factors that must be managed is financial matters. Management of family finances in preparation for a Catholic wedding or what is often called Kuperper is no less important, because after marriage, young couples or newly married couples must be aware of the consequences that will follow, including financial management. This service partner, namely the Family Commission of the Dean of the Archdiocese of Palembang, entrusted this material to a team of lecturers from the Faculty of Business and Accounting, Musi Charitas Catholic University, Palembang because they do not have the competence to provide financial planning training, this financial planning training is a necessity for young couples who in the near future will build a household. This training was attended by 56 participants from various parishes, but 45 participants filled out the questionnaire distributed by the team. The Financial Planning Training on the importance of family financial education has gone well, and partners also expressed their gratitude for holding this activity, and hoped that similar activities would be held again. Before and after the training the participants were asked to fill out a questionnaire to measure their understanding of financial planning. Output targets in this activity were also quite achieved, with an increase in correct answers after participants attended the training.
\end{abstract}

Keywords: investment, financial management

\section{ABSTRAK}

Keluarga yang baik perlu dipersiapkan lama, sebab keluarga yang baik menjadi faktor utama keselamatan/kesejahteraan pribadi, masyarakat dan Gereja, dalam membangun keluarga Katolik, salah satu faktor penting yang harus dikelola adalah masalah keuangan. Pengelolaan keuangan keluarga dalam persiapan pernikahan Katolik atau yang sering di sebut Kuperper 
menjadi materi yang tidak kalah penting,karena setelah menikah, pasangan muda atau pasangan yang baru menikah harus sadar akan konsekuensi yang akan mengikuti, termasuk tentang pengelolaan keuangan. Mitra pengabdian ini yakni Komisi Keluarga Dekanat 1 Keuskupan Agung Palembang mempercayakan pemberian materi ini pada Tim dosen-dosen Fakultas Bisnis dan Akuntansi Universitas Katolik Musi Charitas Palembang dikarenakan tidak memiliki kompetensi untuk memberikan pelatihan perencanaan keuangan, pelatihan perencanaan keuangan ini merupakan suatu kebutuhan bagi pasangan muda yang dalam waktu dekat akan membangun rumah tangga. Pelatihan ini diikuti 56 peserta dari berbagai paroki, namun yang mengisi kuesioner yang dibagikan tim sebanyak 45 peserta. Pelatihan Perencanaan Keuangan pentingnya edukasi keuangan keluarga telah berjalan dengan baik, dan mitra juga menyatakan rasa terima kasihnya atas terselenggaranya kegiatan ini, serta mengharapkan kegiatan serupa untuk diadakan lagi. Sebelum dan setelah dilakukan pelatihan para peserta diminta untuk mengisi kuesioner untuk mengukur pemahaman mereka tentang perencanaan keuangan. Sasaran (target luaran) dalam kegiatan ini juga cukup tercapai, dengan adanya peningkatan jawaban yang benar setelah peserta mengikuti pelatihan.

Kata kunci: investasi, pengelolaan keuangan

\section{PENDAHULUAN}

Keluarga-keluarga Katolik diharapkan mampu mengelola keuangan keluarga dengan cerdas, cerdas dalam mengelola sumber dana dan penggunaan dana(uang) yang mereka miliki, karena keuangan adalah salah satu faktor yang dibutuhkan untuk mendukung kebersamaan seluruh hidup dan demi kesejahteraan pasutri dan anak-anak. Keuangan dalam keluarga haruslah dipahami sebagai sarana bukan sebagai tujuan. Pengelolaan keuangan keluarga dalam persiapan pernikahan Katolik atau yang sering di sebut Kuperper menjadi materi yang tidak kalah penting,karena setelah menikah, pasangan muda atau pasangan yang baru menikah harus sadar akan konsekuensi yang akan mengikuti, termasuk tentang pengelolaan keuangan. Perlu diketahui, meski ada istilah bahwa uang bukan segalanya, didalam pernikahan pengelolaan keuangan harus benar dan matang. Dalam pernikahan masalah keuangan sensitif, yang bertanggung jawab dalam masalah pengelolaan keuangan tidak bisa dibebankan pada istri saja atau suami saja. Keduanya harus saling berkomunikasi agar perlahan bisa mandiri mengatur keuangan. Idealnya dalam sebuah keluarga keuangan dikelola bersama-sama antara suami-istri (Ghozie, 2017)

Sebelum membentuk institusi perkawinan, calon-calon keluarga muda di dalam gereja Katolik diharuskan mengikuti Kursus Persiapan
Perkawinan, kursus ini memberikan harapan tercapainya keluarga yang baik, bagi Gereja dan masyarakat. KPP memberi kepada muda-mudi bekal dalam hidup keluarga katolik. Demikian juga di Keuskupan Agung Palembang.dalam satu tahun diadakan 4 kali kursus persiapan perkawinan, yakni di bulan Febuari, Mei, Agustus dan Oktober. Di dalam Kuperper, ada berbagai materi yang diberikan, dan salah satu materi yang juga tidak kalah pentingnya adalah materi tentang ekonomi rumah tangga atau manajemen keuangan keluarga. Ekonomi rumah tangga bukanlah tujuan, melainkan sarana yang (harus) menunjang dan memungkinkan penghayatan iman, yang mau dicapai adalah kesejahteraan bagi semua orang serta peningkatan mutu hidup menurut kehendak Tuhan (Indonesia, 1975)

Sebagian besar peserta pelatihan ini adalah generasi milenial ( yang lahir antara tahun 1980-1999 ) yang umumnya dinilai belum bisa memilah antara kebutuhan dan keinginan. Generasi milenial cenderung memenuhi aktualisasi diri untuk mengikuti gaya hidup. Perencana keuangan (Ghozie, 2014) mengingatkan pentingnya perencanaan keuangan, dan jika tidak dilakukan sedini mungkin,maka risiko terberatnya adalah gagal pensiun dengan nyaman. Perencanaan keuangan mutlak dilakukan demi menghadapi masa depan keuangan yang lebih baik (Sitohang, 2017) 
Pengelolaan keuangan keluarga dalam persiapan pernikahan Katolik atau yang sering di sebut Kuperper menjadi materi yang tidak kalah penting, karena setelah menikah, pasangan muda atau pasangan yang baru menikah harus sadar akan konsekuensi yang akan mengikuti, termasuk tentang pengelolaan keuangan.

\section{PERMASALAHAN MITRA}

Saat ini mitra tidak memiliki kompetensi untuk memberikan pelatihan perencanaan keuangan, pelatihan perencanaan keuangan ini merupakan suatu kebutuhan bagi pasangan muda yang dalam waktu dekat akan membangun rumah tangga.

\section{METODE PELAKSANAAN Persiapan}

Tim menghubungi Romo RD Petrus Sukino selaku wakil pihak mitra, untuk kerjasama pelaksanaan kegiatan, setelah menyetujui, maka ditandatangani surat keterangan kesediaan kerja sama tanggal 24 April 2021.

Bulan Juli 2021 Tim kembali menghubungi Romo RD.Petrus Sukino selaku Koordinator Kursus Persiapan Pernikahan Dekanat 1 Keuskupan Agung Palembang untuk membicarakan kegiatan yang akan dilaksanakan, kepastian jadwal penyelenggaraan diterima tim tanggal 4 Agustus melalui WA.

\section{Pemberian Materi}

Pemberian materi selain berupa ceramah, juga simulasi dan pelatihan. Kegiatan dilakukan secara daring, dimulai dengan diskusi dalam tim, pembahasan dalam diskusi meliputi topik apa yang akan diberikan, bagaimana metode penyampaian , keterlibatan mahasiswa dalam kegiatan dan juga pemberian hadiah bagi peserta. setelah beberapa kali diskusi, diputuskan topik kegiatan pengabdian masyarakat membahas mengenai "Pelatihan Perencanaan Keuangan : Pentingnya Edukasi Keuangan Keluarga”.

Sebelum pelaksanaan pelatihan, tim meminta peserta untuk mengisi kuesioner sebelum dan setelah pelatihan, yang bertujuan sebagai masukan bagi tim untuk mengetahui efektifitas pemberian materi .Peserta diminta untuk mengisi kuesioner sebelum pelatihan dan setelah pelatihan peserta juga diminta kembali untuk mengisi kuesioner. Item pengukuran dalam kuesioner yang digunakan diadopsi dari "Buku Seri Literasi Keuangan Indonesia :Perencanaan Keuangan Ibu Rumah Tangga." (Keuangan, 2013).

\section{Waktu Pelaksanaan}

Kegiatan diselenggarakan tanggal 26 Agustus 2021. Kegiatan masih dilakukan melalui daring (zoom) mengingat kondisi pandemi covid 19 yang masih berlanjut, yang tidak memungkinkan pemberian materi secara tatap muka dengan peserta.

Pelaksanaan kegiatan tanggal 26 Agustus 2021 mulai pukul 19.00 s.d 21.00 dilakukan secara daring melalui zoom meeting, dibagi menjadi dua sesi, sesi pertama pemaparan materi "Pelatihan Perencanaan Keuangan : Pentingnya Edukasi Keuangan Keluarga", yang meliputi, Pedoman Pastoral, pokok masalah ekonomi rumah tangga, komunikasi keuangan ( komunikasi keuangan sebelum menikah, komunikasi keuangan jika mau membantu keluarga dpasangan diluar keluarga inti)

,pengelolaan alokasi dana, berapa besar alokasi dana untuk sosial, untuk hutang, untuk dana darurat ,untuk asuransi ( proteksi) , untuk investasi dan dana pendidikan anak, selain itu pada bagian-bagian tertentu di berikan juga beberapa firman dalam Kitab Suci yang memberikan peneguhan dalam kaitan dengan pengelolaan keuangan. Sesi kedua merupakan pelatihan dan simulasi, serta tanya jawab, peserta yang bertanya dan beruntung akan mendapatkan doorprize berupa voucher pulsa sebesar Rp 50.000, selain itu sebanyak 2 peserta yang mengisi kuesioner dipilih secara acak juga diberikan doorprize berupa voucher pulsa sebesar Rp 50.000 per orang.

Setelah selesai pelaksanaan tanggal 26 Agustus 2021 tim melanjutkan kerja untuk penyusunan laporan, kegiatan yang dilakukan dalam rangka penyusunan laporan antara lain merekap presensi peserta, mengolah data kuesioner, menghubungi peserta yang beruntung mendapatkan doorprize, membuat laporan, menyusun luaran (publikasi), dan 
mempersiapkan materi untuk seminar laporan. Kegiatan ini berlangsung dari awal bulan September sampai dengan akhir bulan November 2021.Penyerahan laporan, presentasi seminar direncanakan bulan Desember 2021. Setelah seminar, akan direvisi sesuai masukanmasukan yang diperoleh saat seminar.

\section{Karakteristik Mitra}

Berikut informasi lengkap mengenai karakteristik peserta pengabdian yang hadir berdasarkan beberapa data seperti gender, usia, tingkat pendidikan, status pekerjaan.

Tabel 1 Sebaran Peserta Pengabdian

Masyarakat Berdasarkan Gender

\begin{tabular}{ccc}
\multicolumn{3}{c}{ Masyarakat Berdasarkan Gender } \\
\hline $\begin{array}{c}\text { Distribusi } \\
\text { Frekuensi } \\
\text { Responden } \\
\text { (Berdasarkan } \\
\text { Gender) }\end{array}$ & Frekuensi & Persentase \\
\hline Pria & & \\
Wanita & 22 & $51,1 \%$ \\
Jumlah & 23 & $48,9 \%$ \\
\hline
\end{tabular}

Sumber : data primer diolah, 2021

Berdasarkan gender, jumlah peserta yang mengikuti kegiatan pengabdian masyarakat ini dan mengembalikan kuesioner adalah 22 orang pria $(51,1 \%)$ dan 23 wanita $(48,9 \%)$.

Tabel 2 : Sebaran Peserta Pengabdian Masyarakat Berdasarkan Usia

$\begin{array}{lll}\text { Distribusi } & \text { Frekuensi } & \text { Persentase } \\ \text { Frekuensi } & & \\ \text { Responden } & & \end{array}$

(Berdasarkan Usia)

\begin{tabular}{|ccc|}
\hline $\begin{array}{c}\text { Kurang dari 23 } \\
\text { tahun }\end{array}$ & 3 & $6,7 \%$ \\
$\begin{array}{c}\mathbf{2 3} \text { tahun sampai } 27 \\
\text { tahun }\end{array}$ & 15 & $33,3 \%$ \\
$\begin{array}{c}\text { Lebih dari 27 tahun } \\
\text { Jumlah }\end{array}$ & 27 & $60 \%$ \\
\hline
\end{tabular}

Sumber : data primer diolah,2021

Berdasarkan usia, peserta yang mengikuti kegiatan pengabdian masyarakat ini adalah 3 orang $(6,7 \%)$ berusia kurang dari 23 tahun, 15 orang $(33,3 \%)$ berusia 23 tahun sampai dengan 27 tahun serta 27 orang (60\%) berusia lebih dari 27 tahun.
Tabel 3 : Sebaran Peserta Pengabdian Masyarakat Berdasarkan Jenis Pekerjaan Utama

\begin{tabular}{lll} 
Distribusi & Frekuensi & Persentase \\
Frekuensi & & \\
Responden & & \\
\hline
\end{tabular}

(Berdasarkan Jenis

Pekerjaan Utama)

\begin{tabular}{ccc}
\hline Karyawan & 11 & $24,4 \%$ \\
Bisnis (Wirausaha) & 34 & $75,6 \%$ \\
Jumlah & 45 & $100 \%$ \\
\hline
\end{tabular}

Sumber : data primer diolah, 2021

Berdasarkan jenis pekerjaan, peserta yang mengikuti kegiatan pengabdian masyarakat ini adalah 11 orang $(24,4 \%)$ sebagai karyawan dan 34 orang $(75,6 \%)$ sebagai pebisnis (wirausahawan).

Berdasarkan masa kerja, peserta yang mengikuti kegiatan pengabdian masyarakat ini adalah 25 orang $(55,6 \%)$ memiliki masa kerja kurang dari 5 tahun, 16 orang $(35,6 \%)$ memiliki masa kerja 5 sampai dengan 10 tahun, 3 orang $(6,7 \%)$ memiliki masa kerja 10 sampai dengan 15 tahun, dan 1 orang $(2,2 \%)$ memiliki masa kerja lebih dari 15 tahun. Berdasarkan tingkat pendidikan akhir, peserta yang mengikuti kegiatan pengabdian masyarakat ini adalah 2 orang $(4,4 \%)$ memiliki pendidikan akhir SMP/Sederajat, 11 orang $(24,4 \%)$ memiliki pendidikan akhir SMA/Sederajat, 1 orang (2,2\%) memiliki pendidikan akhir akademi, 29 orang $(64,4 \%)$ memiliki pendidikan akhir Sarjana, serta 2 orang $(4,4 \%)$ memiliki pendidikan akhir Pasca Sarjana.

Berdasarkan aspek kemenarikan topik kegiatan, 1 orang $(2,2 \%)$ peserta menyatakan tidak setuju, 2 orang $(4,4 \%)$ peserta menyatakan netral, 15 orang $(33,3 \%)$ peserta setuju, dan 27 orang $(60 \%)$ peserta sangat setuju bahwa topik kegiatan menarik. Berdasarkan kemenarikan bahan/materi, 1 orang $(2,2 \%)$ peserta menyatakan tidak setuju, 2 orang $(4,4 \%)$ peserta menyatakan netral, 15 orang $(33 \%)$ peserta setuju dan 27 orang $(60 \%)$ peserta sangat setuju bahwa bahan/materi kegiatan menarik. Berdasarkan kejelasan penyajian bahan/materi, 1 orang $(2,2 \%)$ peserta menyatakan tidak setuju, 1 orang $(2,2 \%)$ peserta menyatakan netral, 13 orang $(28,9 \%)$ peserta setuju dan 30 orang 
$(66,7 \%)$ peserta sangat setuju bahwa penyajian bahan/materijelas. Berdasarkan kemenarikan bentuk kegiatan secara umum, 1 orang $(2,2 \%)$ peserta menyatakan netral, 15 orang $(33,3 \%)$ peserta menjawab setuju dan 29 orang $(64,4 \%)$ peserta menjawab sangat setuju bahwa bentuk kegiatan secara umum menarik. Berdasarkan kebermanfaatan kegiatan, 9 orang $(20 \%)$ peserta menjawab setuju dan 36 orang $(80 \%)$ peserta menjawab sangat setuju bahwa kegiatan ini sangat bermanfaat.

\section{HASIL DAN PEMBAHASAN}

Sebelum dan sesudah kegiatan pengabdian masyarakat dilaksanakan, peserta diminta untuk mengisi kuesioner yang berisikan pernyataan dengan pilihan ganda seputar pengetahuan tentang perencanaan keuangan keluarga. Kuesioner sebelum dan sesudah kegiatan bertujuan untuk mengetahui keefektifan pemberian materi.

Berikut ini adalah hasil perbandingan pemahaman peserta sebelum dan setelah diberikan pelatihan.

Pertanyaan pertama merupakan pertanyaan dasar sebelum peserta membentuk keluarga, dari jawaban sebelum dilakukan pelatihan sebanyak $6,7 \%$ peserta memilih sumber dana untuk mengadakan pesta pernikahan berasal dari hutang keluarga, dan $4,4 \%$ berasal dari sumbangan dari para undangan, $88,9 \%$ berasal dari uang sendiri sesuai kemampuan. Pada saat pelatihan, peseta dijelaskan bahwa sedapat mungkin sumber dana untuk pesta pernikahan tidak berasal dari hutang, sangat baik jika pesta pernikahan berasal dari uang sendiri dan mengadakan pesta sesuai dengan kemampuan. Jawaban peserta setelah pelatihan ada peningkatan jawaban yang benar (sebesar 4,4 $\%$ ) yakni dari $88,9 \%$ menjadi $93,3 \%$.

Pertanyaan kedua bertujuan untuk mengetahui pandangan peserta mengenai tanggung jawab didalam menanggung perekonomian keluarga yang merupakan tanggung jawab suami dan istri, jawaban peserta sebelum pelatihan sebanyak $77,8 \%$ telah memiliki pandangan yang sesuai, namun $22,2 \%$ peserta menganggap suami lah yang bertanggung jawab atas perekonomian keluarga. Dalam pelatihan dijelaskan bahwa tanggung jawab atas perekonomian merupakan tanggung jawab bersama suami dan istri, setelah pelatihan ada kenaikan jumlah jawaban yang benar dari $77,8 \%$ menjadi $84,4 \%$ atau sekitar $10,6 \%$.

Pertanyaan ketiga mengarah pada keterbukaan antar suami dan istri dalam mengatur ekonomi keluarga, untuk pertanyaan ini semua peserta menjawab dengan tepat baik sebelum pelatihan. Saat pelatihan di jelaskan pentingnya saling keterbukaan didalam mengatur ekonomi keluarga, dalam mengatur ekonomi keluarga yang paling penting adalah komunikasi secara terbuka antara suami dan istri. Setelah pelatihan ada kenaikan jawaban yang benar dari $97,8 \%$ menjadi $100 \%$.

Pertanyaan no 4, merupakan pengetahuan tentang penghasilan yang diperoleh baik penghasilan aktif maupun penghasilan pasif. Pada saat pelatihan dijelaskan mengenai penghasilan aktif dan pasif, materi ini bertujuan untuk memotivasi peserta untk melakukan investasi sehingga diharapkan memperoleh penghasilan pasif. Sebelum pelatihan yang menjawab benar sebesar $68,9 \%$, dan mengalami peningkatan sebesar 13,3 \% setelah mengikuti pelatihan menjadi $82,2 \%$.

Didalam pengelolaan keuangan, salah satu alokasi dana adalah alokasi dana untuk pendidikan anak. Materi ini diberikan dengan tujuan agar peserta juga sudah mengantisipasi pendidikan untuk anak-anak yang akan menjadi bagian keluarga inti. Alokasi dana untuk pendidikan anak idealnya $20 \%$ dari penghasilan , sebelum pelatihan $53,3 \%$ yang menjawab benar, dan setelah pelatihan mengalami kenaikan menjadi $64,4 \%$, atau kenaikkan sebesar $\mathbf{1 0 \%}$.

Hal lain yang dijelaskan dalam pelatihan adalah pentingnya mempersiapkan dana darurat. Adapun besarnya dana darurat (minimal) yang harus dipersiapkan adalah sebesar 3 kali biaya bulanan. Sebelum pelatihan sebesar 51,1\% yang menjawab dengan tepat, namun setelah pelatihan yang menjawab dengan tepat sebanyak $73,3 \%$. Ada kenaikan sebesar $22,2 \%$.

Berdasarkan dengan penjelasan yang diberikan pada peserta mengenai hutang, adapun yang ditekankan dalam pelatihan bahwa 
penggunaan hutang harus bijak, jika keluarga memiliki hutang sebaiknya dalam jumlah yang tidak melebihi $30 \%$ dari penghasilan, peserta yang menjawab benar sebelum pelatihan sebesar $62,2 \%$ dan setelah pelatihan mengalami penurunan menjadi $86,7 \%$. Ada kenaikan jawaban yang benar sebesar $\mathbf{2 4 , 5 \%}$.

Berdasarkan dengan penjelasan yang diberikan pada peserta mengenai hutang,jika berhutang untuk hal yang produktif, sebelum pelatihan semua peserta ada yang menjawab berutang untuk membeli perabot sebesar $6,7 \%$ dan berutang untuk membuka usaha sebesar 93,3\%. Namun setelah pelatihan mengalami yang menjawab dengan benar $100 \%$.

Berdasarkan dengan penjelasan tentang asuransi untuk tujuan, ditekankan bahwa tujuan membeli asuransi adalah untuk proteksi dan bukan untuk investasi. Sebelum pelatihan $17,8 \%$ peserta masih menjawab tujuan asuransi adalah untuk investasi, dan setelah pelatihan yang menjawab tujuan asuransi untuk investasi berkurang menjadi $13,3 \%$. Sebelum pelatihan peserta yang menjawab membeli asuransi untuk proteksi sebesar $82,2 \%$ namun setelah pelatihan mengalami kenaikan jawaban benar sebesar 4,5\% menjadi $86,7 \%$.

Berdasarkan dengan pertanyaan diatas, peserta diingatkan jangan sampai mengorbankan kebutuhan keluarga inti untuk membantu keluarga yang bukan inti. Sebelum pelatihan peserta yang menjawab meminjamkan uang pendidikan kepada keluarga sebesar $6,7 \%$ dan yang mengutamakan dana pendidikan untuk keluarga inti sebesar 93,3\%. Namun, setelah pelatihan mengalami peningkatan jawaban benar sebesar $4,5 \%$ menjadi $97,8 \%$.

\section{Tabel 4 : Tingkat Pengetahuan Peserta Terkait dengan Perencanaan Keuangan Keluarga Sebelum dan Sesudah Mengikuti Kegiatan}

\begin{tabular}{|c|c|c|c|}
\hline \multirow{2}{*}{ No. } & \multirow{2}{*}{$\begin{array}{l}\text { Pertanyaan seputar } \\
\text { Pengetahuan } \\
\text { Tentang } \\
\text { Perencanaan } \\
\text { Keuangan Keluarga } \\
\end{array}$} & \multicolumn{2}{|c|}{$\begin{array}{l}\text { Persentase } \\
\text { Jawaban Benar }\end{array}$} \\
\hline & & Sebelum & Sesudah \\
\hline 1 & $\begin{array}{l}\text { Dari mana dana untuk } \\
\text { mengadakan pesta } \\
\text { pernikahan? }\end{array}$ & $\begin{array}{c}88, \\
9 \%\end{array}$ & $\begin{array}{c}93, \\
3 \%\end{array}$ \\
\hline
\end{tabular}

\begin{tabular}{|c|c|c|c|}
\hline 2 & $\begin{array}{l}\text { Siapa yang } \\
\text { bertanggung jawab } \\
\text { atas perekonomian } \\
\text { keluarga? }\end{array}$ & $\begin{array}{l}77, \\
8 \%\end{array}$ & ${ }^{84} \%^{84,}$ \\
\hline 3 & $\begin{array}{l}\text { Bagaimana cara } \\
\text { mengatur ekonomi } \\
\text { keluarga? }\end{array}$ & $\begin{array}{l}97, \\
8 \%\end{array}$ & $0 \%$ \\
\hline 4 & $\begin{array}{l}\text { Penghasilan yang } \\
\text { berupa bunga atau } \\
\text { hasil (return) dari } \\
\text { investasi yaitu .. }\end{array}$ & $\begin{array}{l}68, \\
9 \%\end{array}$ & $\begin{array}{l}82, \\
2 \%\end{array}$ \\
\hline 5 & $\begin{array}{l}\text { Alokasi dana untuk } \\
\text { pendidikan anak } \\
\text { idealnya.. }\end{array}$ & $\begin{array}{l}53, \\
3 \%\end{array}$ & $\begin{array}{l}64, \\
4 \%\end{array}$ \\
\hline 6 & $\begin{array}{l}\text { Berapakah besar dana } \\
\text { darurat (minimal) yang } \\
\text { harus disiapkan? }\end{array}$ & $1 \%$ & $\begin{array}{l}73, \\
3 \%\end{array}$ \\
\hline 7 & $\begin{array}{l}\text { Dalam mengelola } \\
\text { penghasilan, manakah } \\
\text { besarnya alokasi dana } \\
\text { yang paling beanr } \\
\text { berikut ini? }\end{array}$ & $\begin{array}{l}62, \\
2 \%\end{array}$ & $\begin{array}{l}86, \\
7 \%\end{array}$ \\
\hline 8 & $\begin{array}{l}\text { Manakah dibawah ini } \\
\text { yang termasuk utang } \\
\text { produktif? }\end{array}$ & $\begin{array}{l}93, \\
3 \%\end{array}$ & $0 \%$ \\
\hline 9 & $\begin{array}{l}\text { Kita membeli asuransi } \\
\text { untuk tujuan .. }\end{array}$ & $\begin{array}{l}82, \\
2 \%\end{array}$ & $\begin{array}{l}86, \\
7 \%\end{array}$ \\
\hline 10 & $\begin{array}{l}\text { Apabila ada salah satu } \\
\text { dari keluarga besar } \\
\text { yang ingin meminjam } \\
\text { uang untuk tambahan } \\
\text { membuka usaha } \\
\text { mereka, keluarga Anda } \\
\text { tidak memiliki dana } \\
\text { berlebih selain dana } \\
\text { yang akan } \\
\text { dipergunakan untuk } \\
\text { uang pendidikan anak } \\
\text { Anda, apa yang Anda } \\
\text { lakukan? }\end{array}$ & $\begin{array}{l}93, \\
3 \%\end{array}$ & $\begin{array}{l}97, \\
8 \%\end{array}$ \\
\hline
\end{tabular}

Secara umum, dari 10 pertanyaan kuisioner untuk mengukur pengetahuan mengenai perencanaan keuangan keluarga, rata-rata jawaban benar dari peserta saat sebelum mengikuti kegiatan adalah sebesar 76,88\% sedangkan rata-rata jawaban benar dari peserta sesudah mengikuti kegiatan adalah sebesar $86,88 \%$. Adapun pertanyaan yang mengalami kenaikan jawaban yang benar cukup signifikan yaitu terkait hutang ( peningkatan jawaban benar $24,5 \%$ ) dan pertanyaan berkaitan dengan dana darurat (peningkatan jawaban benar 
sebesar 22,2\%). Hal ini menunjukkan sesudah mengikuti kegiatan pengabdian ini, pengetahuan peserta mengenai perencanaan keuangan keluarga meningkat.

\section{SIMPULAN}

Secara umum, kegiatan pengabdian masyarakat: "Pelatihan Perencanaan Keuangan : Pentingnya Edukasi Keuangan Keluarga" telah berjalan dengan baik, dan mitra juga menyatakan rasa terima kasihnya atas terselenggaranya kegiatan ini, serta mengharapkan kegiatan serupa untuk diadakan lagi pada periode berikutnya.

Secara umum, dari 10 pertanyaan kuesioner untuk mengukur pengetahuan mengenai ada peningkatan sebelum dan sesudah pelatihan. Presentase peningkatan jawaban yang cukup tinggi adalah pertanyaan tentang Pengeluaran untuk utang dan minimal dana darurat yang dimiliki.

Sasaran (target luaran) dalam kegiatan ini juga cukup tercapai , dengan adanya peningkatan jawaban yang benar setelah peserta mengikuti pelatihan.

Peserta juga cukup aktif mengikuti kegiatan di mana terlihat dari sesi tanya jawab dengan tim pengabdian yang berjalan cukup baik.

Selain itu, indikator keberhasilan pelaksanaan kegiatan ini juga terlihat dari hasil penilaian kuesioner dan masukan secara terbuka yang diberikan oleh peserta pelatihan.

\section{UCAPAN TERIMA KASIH}

Pada kesempatan ini, kami segenap tim pengabdian masyarakat ingin mengucapakan terima kasih pada berbagai pihak yang telah memberikan sumbangsih (baik berupa pemikiran, dana, maupun waktu) bagi terwujudnya kegiatan pengabdian masyarakat ini sampai dengan penyusunan laporan kegiatan, diantaranya: Rektor Universitas Katolik Musi Charitas Palembang atas izin yang diberikan untuk melakukan kegiatan pengabdian kepada masyarakat. Dekan Fakultas Bisnis dan Akuntansi Universitas Katolik Musi Charitas Palembang atas izin yang diberikan untuk melakukan kegiatan pengabdian kepada masyarakat. Kepala LPPM Universitas Katolik Musi Charitas Palembang atas pengarahan yang diberikan terkait dengan administratif pengajuan sampai dengan pelaporan kegiatan pengabdian kepada masyarakat. Romo RD Petrus Sukino selaku Koordinator Kursus Persiapan Pernikahan Dekanat 1 Keuskupan Agung Palembang. Rekan-rekan dosen di Fakultas Bisnis dan Akuntansi atas masukan dan saran terkait dengan kegiatan pengabdian perencanaan keuangan keluarga ini.

Dan pihak-pihak lainnya yang tidak dapat disebutkan satu per satu namun turut memberikan bantuan yang bermanfaat bagi kelancaran proses pelaksanaan kegiatan pengabdian masyarakat ini

\section{REFERENSI}

Ghozie, P. H. (2014). Make It Happen. Gramedia Pustaka Utama.

Ghozie, P. H. (2017). Problema Keuangan. Tabloid Kontan, 11-XXII.

Indonesia, K. W. G. (1975). Pedoman Pastoral $K W I$.

Keuangan, O. J. (2013). Buku Seri Literasi Keuangan Indonesia:Perencanaan Keuangan Ibu Rumah Tangga.

Sitohang, S. E. H. (2017). Tiga Hal Penting Tentang Investasi Untuk Pasangan Muda, yang Harus Anda Praktikkan! Finansialku. https://www.finansialku.com/investasiuntuk-pasangan-muda/ 